\title{
EVALUATION OF STUDENT EXPERIENCES IN A DEVELOPED BLENDED LEARNING COURSE IN ENGINEERING
}

\author{
Mohammadali Sepehri ${ }^{*}$, L. Francisco Vargas M. ${ }^{2}$, and Samer Adeeb ${ }^{l}$ \\ ${ }^{1}$ Department of Civil and Environmental Engineering, Faculty of Engineering \\ ${ }^{2}$ Centre for Teaching and Learning \\ University of Alberta \\ *msepehri@ualberta.ca
}

Blended learning is an instructional approach where traditional face-to-face instructional time and computermediated learning are combined ([1] and [4]). Higher education institutions are progressively moving towards a blended learning model because of the opportunities that blended learning offers with respect to increasing engaged inquiry in the classroom, the need to use classroom space more efficiently, as well as the need for greater flexibility in scheduling with changing student demographics ([1] and [2]) The main motivation for implementing a blended learning approach in one of the key engineering undergraduate course in the Civil and Environmental Engineering program at the University of Alberta emerged from a need to improve student engagement and satisfaction.

This study distinguished three levels of engagement: behavioral, emotional and cognitive [3]. Behavioral engagement refers to course participation, and includes academic, social and extracurricular activities that are considered critical for achieving positive academic outcomes. Emotional engagement is concerned with the various reactions to instructors, classmates or the institution that are supposed to influence willingness to complete activities. Cognitive engagement refers to student investment and readiness to put in the work necessary to understand complex ideas and master skills that are being taught. This study distinguished two levels of student satisfaction: satisfaction with the course format, and satisfaction with blended learning as indicated upon completion of the course [5].

The main objectives of this paper are to discuss the blended learning approach implemented in CivE 270 (Mechanics of Deformable Bodies), and to describe student experiences, focusing on their engagement, and satisfaction. During this study, a blended learning program was developed for all 11 laboratories sessions of the course. These labs were combinations of experimental and tutorial labs. Our blended learning approach combined attendance to face-to-face lab sessions with instructors and the use of computer-based instruction to be used before each lab session. Implementing blended learning required to create video tutorials for all laboratory sessions. The main goal of these videos was to prepare students for the actual tasks to be completed in the labs. All videos were uploaded to YouTube, and links were provided to students in their Learning Management System (LMS), allowing them to watch them before attending the session.

A single-case study analysis approach was used in this research. The course has two sections, but the data from each section and their students was described as a single case study. A wide range of quantitative data was collected from students, including pre-and post-surveys, and YouTube analytics. These data are still being collected and analyzed, however, based on the preliminary results, overall student satisfaction is $76 \%$. The overall emotional, cognitive and behavioural student's engagements are $82 \%$, $78 \%$ and $77 \%$, respectively.

\section{References}

[1] Alammary, A., Sheard, J., \& Carbone, A. (2014). Blended Learning in Higher Education: Three Different Design Approaches. Australasian Journal of Educational Technology, 30(4), 440-454.

[2] Bernard, R. M., Borokhovski, E., Schmid, R., Tamim, R., \& Abrami, P. (2014). A meta-analysis of blended learning and technology use in higher education: from the general to the applied. Journal of Computing in Higher Education, 26(1), 87-122. doi:10.1007/s12528013-9077-3

[3] Fredricks, J. A., Blumenfeld, P., Friedel, J., \& Paris, A. (2005). School Engagement. In K. Moore \& L. Lippman (Eds.), What Do Children Need to Flourish? (pp. 305-321): Springer US.

[4] Means, B., Toyama, Y., Murphy, R., \& Baki, M. (2013). The effectiveness of online and blended learning: A metaanalysis of the empirical literature. Teachers College Record, 115(3), 1-47.

[5] Owston, R., York, D., \& Murtha, S. (2013). Student perceptions and achievement in a university blended learning strategic initiative. The Internet and Higher Education, $18, \quad 38-46$. doi:10.1016/j.iheduc.2012.12.003 